\title{
Live coral predation by parrotfishes (Perciformes: Scaridae) in the Abrolhos Bank, eastern Brazil, with comments on the classification of species into functional groups
}

\author{
Ronaldo B. Francini-Filho ${ }^{1,2}$, Rodrigo L. Moura ${ }^{2}$, Camilo M. Ferreira ${ }^{3}$ and \\ Ericka O. C. Coni ${ }^{3}$
}

Parrotfishes (Perciformes: Scaridae) represent a critical functional group on coral reefs because their intense herbivory activity helps in avoiding coral overgrowth by algae. Although feeding preferentially on algae and detritus, some parrotfish species also consume live corals, leading to detrimental effects that may offset the benefits of removing competitive seaweeds. Parrotfish species differ markedly in terms of jaw morphology, foraging activity and extent of substratum excavation, and are typically divided into three functional groups: browsers, scrapers and excavators. The recognition of species within each functional group helps to understand their relative effects in terms of bioerosion, coral fitness and survival, habitat alteration and ecosystem dynamics. Here we report on live coral predation by the Brazilian endemic parrotfishes Scarus trispinosus and Sparisoma amplum in the largest coral reefs of the South Atlantic (Abrolhos Bank, eastern Brazil) and comment on their classification into functional groups based on direct behavioral observations. Scarus trispinosus and Sp. amplum allocated $0.8 \%$ and $8.1 \%$ of their bites to live corals respectively. Sparisoma amplum fed at lower rates, took shorter feeding forays and larger bites than Sc. trispinosus. Bite rates and foray size were negatively correlated to body size for Sc. trispinosus, but not for Sp. amplum. Our results indicate that Sp. amplum may be primarily recognized as an excavating species, as well as the most specialized parrotfish coral predator in Brazil, while Sc. trispinosus may be recognized as a scraper or excavator depending on its body size. This functional classification corresponds to the classification used for the putative sister taxa of Sc. trispinosus (Sc. coeruleus) and the sister taxa of Sp. amplum (Sp. viride) in the Caribbean, indicating that these two congeneric species pairs play similar ecological roles in different geographic regions.

Os budiões (Perciformes: Scaridae) representam um grupo funcional crítico em recifes de corais uma vez que a intensa atividade de herbivoria que desempenham ajuda a evitar a exclusão de corais por algas. Apesar de alimentarem-se preferencialmente de algas e detrito, algumas espécies de budiões também consomem corais vivos, causando efeitos negativos aos corais, os quais podem superar os benefícios decorrentes da remoção de algas. As espécies de budiões diferem acentuadamente em sua morfologia bucal, atividade de forrageio e potencial de escavação do substrato, sendo tipicamente divididas em três grupos funcionais: podadores, raspadores e escavadores. O reconhecimento das espécies nesses grupos funcionais ajuda a entender seus efeitos relativos em termos de bioerosão, condição e sobrevivência de corais, alteração do hábitat e dinâmica do ecossistema. No presente estudo nós registramos a predação de corais vivos pelos budiões endêmicos do Brasil Scarus trispinosus e Sparisoma amplum no maior complexo coralíneo do Atlântico Sul (Banco dos Abrolhos, leste do Brasil) e comentamos sobre a classificação dessas espécies em grupos funcionais com base em observações comportamentais. Scarus trispinosus e Sp. amplum alocaram 0.8\% e 8.1\% de suas mordidas a corais vivos respectivamente. Sparisoma amplum apresentou menores taxas alimentares, menor número de mordidas em seqüência e maior tamanho de mordidas que Sc. trispinosus. A taxa de mordidas e o número de mordidas em seqüência correlacionaram-se negativamente com o tamanho corporal para Sc. trispinosus, mas não para Sp. amplum. Nossos resultados indicam que Sp. amplum pode ser reconhecida como uma espécie primariamente escavadora, além do mais especializado budião predador de corais no Brasil, ao passo que Sc. trispinosus pode ser reconhecida como uma espécie raspadora ou escavadora, dependendo de seu tamanho corporal. Essa classificação funcional é similar àquela aplicada a suposta espécie irmã de Sc. trispinosus (Sc. coeruleus) e para a espécie irmã de Sp. amplum (Sp. viride) no Caribe, indicando que estes dois pares de espécies congenéricas desempenham papéis ecológicos similares em regiões geográficas distintas.

Key words: Foraging behavior, Bioerosion, Grazing scars, Scarus trispinosus, Sparisoma amplum.

${ }^{1}$ Grupo de Pesquisas em Recifes de Corais e Mudanças Globais, Universidade Federal da Bahia, Rua Caetano Moura 123, 40210-340 Salvador, BA, Brazil. rofilho@yahoo.com (RBFF)

${ }^{2}$ Conservation International Brazil, Marine Program, Rua das Palmeiras 451, 45900-000 Caravelas, BA, Brazil. r.moura@conservation.org (RLM) ${ }^{3}$ Centro de Pesquisa e Conservação dos Ecossistemas Aquáticos - BIOTA Aquática, Rua Almirante Ernesto Jr., 41810-400 Salvador, BA, Brazil.camilo_ferreira@yahoo.com.br(CMF), erickacconi@yahoo.com.br(EOCC) 


\section{Introduction}

Parrotfishes (family Scaridae) are primarily herbivorous reef fishes that use their fused beak-like jaws to remove algae and detritus from the substratum. These fishes play a critical functional role in coral reefs because their intense herbivory activity helps in avoiding coral overgrowth by algae (Hughes, 1994; Bellwood et al., 2004). Despite feeding preferentially on algae and detritus, several Caribbean (Sparisoma viride, Scarus vetula, Sc. guacamaia and Sp. aurofrenatum) and Indo-Pacific species (Bolbometopon muricatum, Cetoscarus bicolor, Sc. frenatus, Sc. gibbus and Sc. rivulatus) also consume live corals (Bellwood \& Choat, 1990; Bruggemman et al., 1994a, b; Miller \& Hay, 1998; Bruckner et al., 2000; Bellwood et al., 2003; Reyes-Nivia et al., 2004; Rotjan \& Lewis, 2005). Given the potential negative effects of parrotfishes' corallivory (Van Veghel \& Bak, 1994; Bruckner \& Bruckner, 1998; Miller \& Hay, 1998; Rotjan \& Lewis, 2005) there is a growing concern in understanding its relative contribution to coral fitness and survival (Miller \& Hay, 1998; Rotjan \& Lewis, 2005, 2006).

Three functional groups of parrotfishes are recognized based on morphology and feeding behavior: browsers, scrapers and excavators (Bellwood \& Choat, 1990; Streelman et al., 2002). The separation of species into functional groups is critical for understanding their effects in terms of bioerosion, coral fitness and survival, habitat modification and ecosystem dynamics (Bellwood \& Choat, 1990; Bellwood et al., 2004). Browsers use their discrete teeth to remove food from the substrata without scarring it. Scrapers make shallow bites, leaving only a scrape marked by dislodged algae. Excavators remove large pieces of the substratum while feeding, leaving prominent scars (Bellwood \& Choat, 1990; Streelman et al., 2002). Scrapers take rapid bites and feed at relatively lower rates, while excavators take slow bites and feed at higher rates. Scrapes are generally paired, with two parallel scrapes made by each dental plate, while scars are approximately half as wide as long and usually possess 4-6 deep grooves running along their length (Bellwood \& Choat, 1990).

In the Caribbean, the genus Scarus is represented only by scrapers, and the stoplight parrotfish Sp. viride is the only species functionally recognized as an excavator (Bellwood \& Choat, 1990). Due to its large bite size and high preference for live coral $S p$. viride is considered as the major parrotfish coral predator in the Caribbean (Bruckner \& Bruckner, 1998; Miller \& Hay, 1998; Reyes-Nivia et al., 2004). Adults may take individual bites scattered over coral colony's surface ("spot biting") or repeated, overlapping and methodical bites ("focused biting”) (Bruckner et al., 2000). Focused biting creates large lesions which progressively radiate across the coral surface, sometimes destroying entire colonies (Bruckner \& Bruckner, 1998; Bruckner et al., 2000).

Seven endemic parrotfish species (five Sparisoma and two Scarus) are recognized in the Southwestern Atlantic (Moura et al., 2001; Gasparini et al., 2004), and the phylogeography of Sparisoma in the Atlantic has been re- cently clarified (Robertson et al., 2006). Two recent studies on Brazilian rocky reefs provide information on the foraging activity and diet of Brazilian parrotfishes (see Bonaldo et al., 2005; Ferreira \& Gonçalves, 2006 for further details), but there is no previous evidence of live coral predation. Here we report on live coral predation by Scarus trispinosus and Sparisoma amplum in the Abrolhos Bank, eastern Brazil, and comment on their classification into functional groups, based on direct behavioral observations. This is the first study focusing on parrotfishes' foraging activity encompassing true coral reefs in the South Atlantic Ocean, allowing for a direct comparison with data for closely related parrotfish species from the Caribbean (Robertson et al., 2006).

\section{Material and Methods}

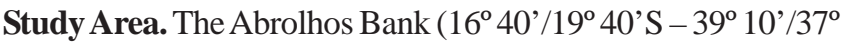
$20^{\prime} \mathrm{W}$ ) is a wide portion of the continental shelf (42000 km²), with depths rarely exceeding $30 \mathrm{~m}$ (Fig. 1). Reef structures display a characteristic form of mushroom-shaped pinnacles, which attain five to $25 \mathrm{~m}$ in height and 20 to $300 \mathrm{~m}$ across their tops. In the Abrolhos Archipelago, rocky bottom is bordered by fringing reefs. Eight of the 18 coral species commonly recorded in the region occur only in Brazil, one of them (Mussismilia braziliensis) endemic to the eastern Brazilian coast alone (Leão \& Kikuchi, 2001). Four species of Sparisoma (Sp. axillare, Sp. amplum, Sp. frondosum, and Sp. radians) and two of Scarus (Sc. trispinosus and Sc. zelindae) occur at the Abrolhos Bank (Moura \& Francini-Filho, 2006).

Underwater observations were conducted using SCUBA in five sites distributed throughout the Abrolhos Bank, covering hard bottom with sparse corals (Abrolhos Archipelago) and typical mushroom-shaped coralline pinnacles that characterize the region (Itacolomis Reef, Parcel dos Abrolhos Reef, Parcel das Paredes Reef and Timbebas Reef; Fig. 1). Detailed quantitative observations on the foraging activity and grazing selectivity of parrotfishes were concentrated at Timbebas Reef during a total of $50 \mathrm{~h}$ between January and March of

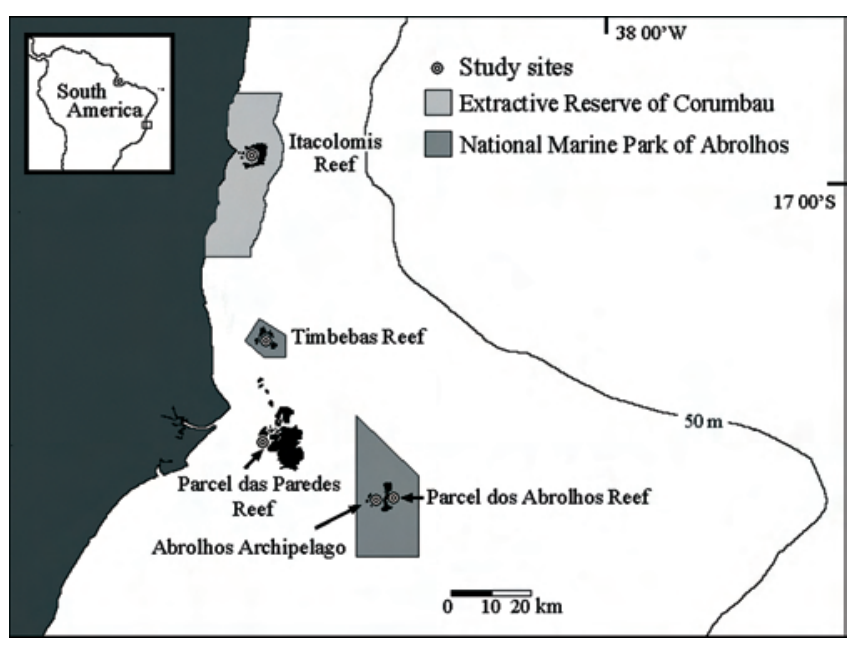

Fig. 1. Map of the Abrolhos Bank, showing study sites. 
2007. In addition, parrotfish individuals preying upon live corals were recorded opportunistically during about $60 \mathrm{~h}$ of observations made at the five sites between 2001 and 2007 (January-March).

Records of live coral predation. When live coral predation was observed, the identity, body size (total length, TL) and life phase of the predatory species, as well as the identity of the preyed coral, were recorded. We avoided inferring predation by recording only bite scars in order to obtain accurate information on the predatory species. Separate observations were made for initial phase (IP) individuals and terminal phase (TP) males (Robertson \& Warner, 1978) only for Sp. amplum, as Sc. trispinosus shows no clear color and morphological changes according to life phase (Moura et al., 2001).

Feeding rates. Feeding rates were quantified using replicate 1-min observation periods (cf. McClanahan et al., 1999), where divers recorded the total number of bites, number of bites per feeding foray and body size of fishes to the nearest centimeter. A foray consisted in a series of bites with no discernible interval between them ( $c f$. Bellwood \& Choat, 1990). Samples were obtained in the same periods of day for all species (08001600 h). Most records were made in a single site (Timbebas Reef), where species overlapped home ranges, thus minimizing the influence of site-associated differences in the substratum ( $c f$. Bellwood and Choat, 1990). Only four additional behavioral samples of small ( $\leq 20 \mathrm{~cm}$ TL) Sp. amplum individuals were obtained at the Abrolhos Archipelago due to the small sample size obtained for this size category at Timbebas Reef. Differences in bite rates and foray size between species and the two life phases of Sp. amplum were evaluated using a $t$ test, with data previously transformed to $\log 10$ (x) (Zar, 1999).

Bite size. Mean surface area of crustose coralline algae removed per bite of Sc. trispinosus and mean surface area of Montastrea cavernosa live tissue removed per bite of Sc. trispinosus and Sp. amplum were estimated using digital photographs taken at Timbebas Reef and Parcel dos Abrolhos Reef. Images were obtained immediately after a given event of predation was recorded and a ruler positioned next to the bite scar or scrape was used for scaling. Surface area of each bite was calculated with Coral Point Count with Excel Extensions software (CPCE; Kohler \& Gill, 2006). Differences in bite size between similar sized ( $>40 \mathrm{~cm}$ TL) Sc. trispinosus and Sp. amplum individuals and between two size categories of Sc. trispinosus (20-40 and $>40 \mathrm{~cm} \mathrm{TL}$ ) were compared with a $t$ test (Zar, 1999). Individuals of Sc. trispinosus $\leq 20 \mathrm{~cm}$ TL were not considered in this latter analysis, as they leave no distinct scars or scrapes while feeding.

Coral abundance and grazing selectivity of Sp. amplum for different coral species. Abundance of different coral species was assessed at the five sites using benthic photo-quadrats ( $\mathrm{n}=10$; cf. Francini-Filho et al., 2008). Each sample was con- stituted by a mosaic of 15 high-resolution digital images totaling $0.7 \mathrm{~m}^{2}$. Quadrats were permanently delimited by fixed metal pins and set at random distances along 20-50 m axis on the pinnacles' tops. Relative cover of different coral species was estimated through the identification of organisms below 300 randomly distributed points per quadrat (i.e. 20 points per photograph) also using CPCE software.

Selectivity for different coral species was determined at Timbebas Reef with Ivlev's electivity index (Ivlev, 1961; Krebs, 1989), as follows:

$E i=(r i-n i)(r i+n i)^{-1}$

where $E_{i}=$ electivity measure for coral species $i, r_{i}=$ proportion of bites taken on coral species $i$ and $n i=$ relative abundance (cover) of coral species $i$ in the studied habitat. Values of $r_{i}$ were calculated by considering the total number of bites taken in a given coral species and its proportion in relation to the total number of bites (i.e. bites taken on live corals and other benthic organisms as well). Electivity index (Ei) varies from -1 to +1 , in which values close to +1 indicate higher preferences and values close to -1 indicate lesser preference or avoidance.

\section{Results}

Records of live coral predation. Only two parrotfish species (Sc. trispinosus and Sp. amplum) were recorded feeding directly on live corals in the Abrolhos Bank. Most opportunistic records of coral predation were concentrated at Timbebas Reef ( $n=18)$, followed by the Abrolhos Archipelago ( $n=11)$, Parcel dos Abrolhos Reef ( $n=9$ ), Parcel das Paredes Reef ( $n$ $=8)$ and Itacolomis Reef $(n=3)$. In general, coral predation was less frequent in sites with low coral cover (Fig. 2).

Sparisoma amplum accounted for most opportunistic records of predation ( $\mathrm{n}=31$ ), preying mainly on $M$. braziliensis $(\mathrm{n}=19)$, followed by M. cavernosa $(\mathrm{n}=7)$ and Siderastrea spp. (n = 5; Table 1). Similarly to its Caribbean sister species $S p$. viride, Sp. amplum removed live tissue underlying skel-

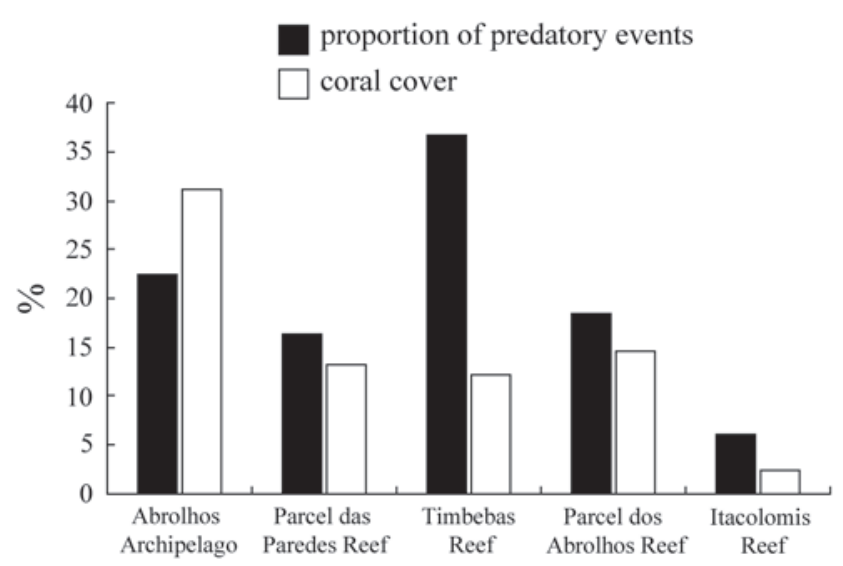

Fig. 2. Proportion of opportunistic records of coral predation by Scarus trispinosus and Sparisoma amplum and coral cover at five sites at the Abrolhos Bank. 
eton adjacent to prominent lesions $(n=5)$, or preyed upon live tissue that was previously undamaged, was not bleached, and did not exhibit signs of disease $(n=26)$ (Bruckner \& Bruckner, 2000). Spot and focused biting were performed by single IP or TP individuals or by roving groups constituted by up to seven individuals, with one to five TP individuals. Mean body size of predatory fishes of Sp. amplum was $36.4 \pm$ 1.4 (SE) cm TL for IP individuals and 46.1 \pm 1.3 (SE) cm TL for TP individuals. Focused biting on M. braziliensis was frequently concentrated on elevated projections at the edges of colonies, resulting in lesions that progressively increased in size, affecting up to $90 \%$ of the surface area of the colonies (Fig. 3a-c). Discrete groups of two to four excavated colonies of $M$. braziliensis were recorded in the edges of territories of Sp. amplum in three sites (Abrolhos Archipelago, Parcel dos Abrolhos Reef and Timbebas Reef; Fig. 3d). These territories were maintained over at least two months, during which colonies were repeatedly excavated.

Scarus trispinosus, the most abundant parrotfish species in the Abrolhos Bank (Francini-Filho \& Moura, 2008), accounted for 18 opportunistic records of live coral predation. Montastrea cavernosa was the most frequently preyed coral species $(\mathrm{n}=11)$, followed by Favia gravida $(\mathrm{n}=3)$, Siderastrea spp. $(\mathrm{n}=2)$, Mussismilia hartti $(\mathrm{n}=1)$ and Porites astreoides
( $\mathrm{n}=1$; Table 1 ). Single $S c$. trispinosus individuals or groups with up to nine individuals engaged in coral predation, performing only spot biting; mean size of predatory fishes was $29.6 \pm 1.3$ (SE) cm TL. Individuals $<20$ cm TL were occasionally recorded grazing over live coral, but never leaving a distinct scrape and apparently removing only a thin layer of mucus and cyanobacteria over the coral tissue. Some colonies of $M$. cavernosa within territories of Sc. trispinosus were observed to be grazed repeatedly over a period of at least two months. Tissue regenerating over damaged skeleton became pale, generally resembling bleached tissue (see Fig. 4c and Sánchez et al., 2004 for similar findings).

Feeding rates. Thirty-five individuals of Sc. trispinosus and 28 of Sp. amplum (15 IP and 13 TP) were sampled for feeding rate estimates. Bite rates and foray size were negatively correlated to body size for $S c$. trispinosus, but not for Sp. amplum (Fig. 5). Sparisoma amplum fed at lower rates $(t=4.20$, $\mathrm{p}<$ $0.001)$ and took fewer bites per foray $(t=5.20$, $\mathrm{p}<0.001)$ than Sc. trispinosus. Foray size, but not bite rate, also varied significantly according to life phase of Sp. amplum (foray size: $t$ $=2.10, \mathrm{p}=0.04$; bite rate: $t=1.15, \mathrm{p}=0.26$ ), with TP individuals taking shorter forays than IP ones (Table 2).

Seventeen additional records of live coral predation by
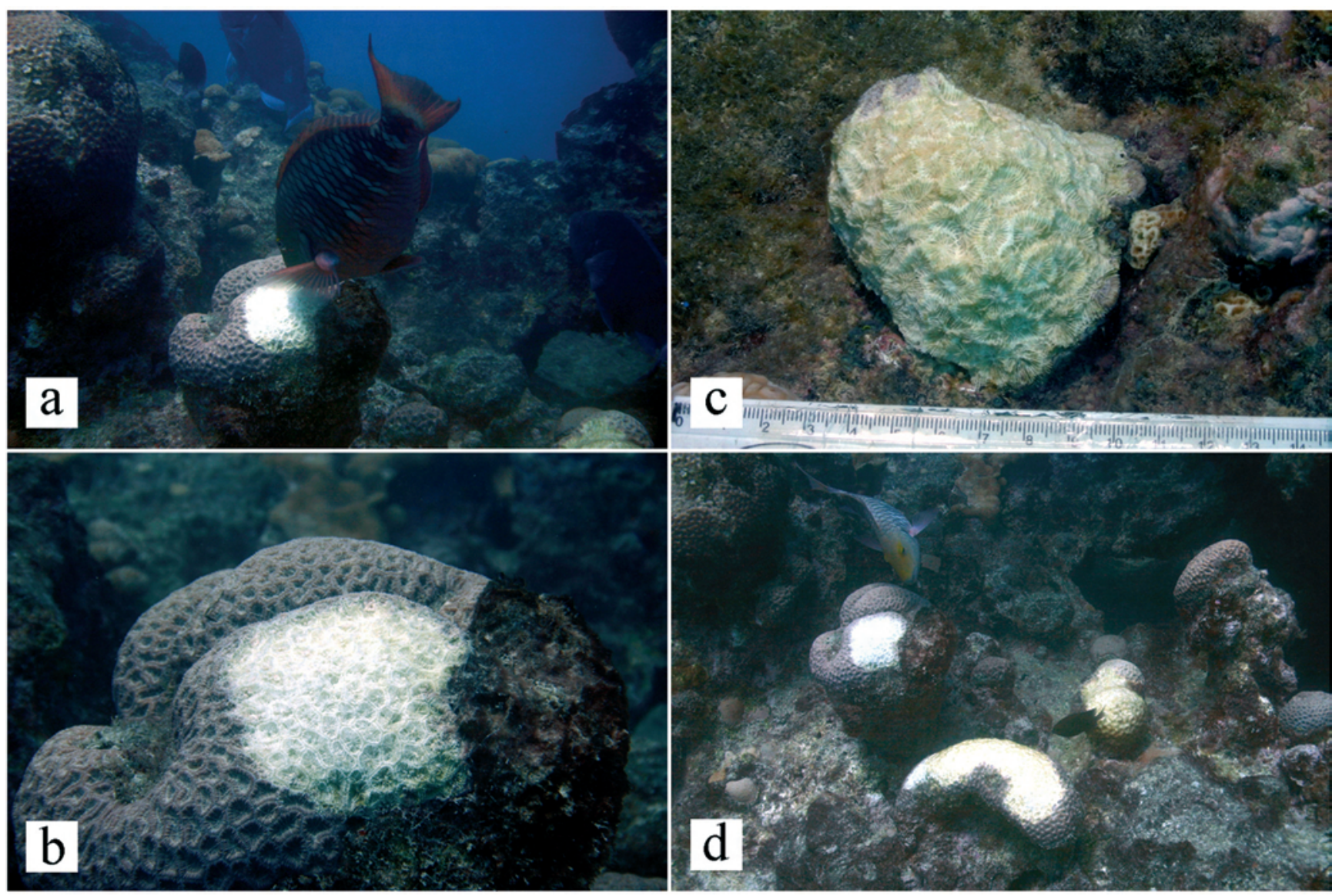

Fig. 3. Focused biting behavior by Sparisoma amplum. (a) Initial-phase individual biting a colony of Mussismilia braziliensis; (b) partial and (c) almost complete coral colony mortality due to Sp. amplum predation; (d) a discrete group of excavated colonies of M. braziliensis on the edge of a Sp. amplum territory. 
parrotfishes were made at Timbebas Reef during behavioral observations. Scarus trispinosus and Sp. amplum allocated $0.8 \%$ and $8.1 \%$ of their bites to live corals respectively. Initial phase and TP Sp. amplum individuals allocated $7.6 \%$ and $8.9 \%$ of their bites to live coral respectively. Mussismilia braziliensis was the most frequently preyed coral species (n

Table 1. Opportunistic records of live coral predation by Scarus trispinosus and Sparisoma amplum in the Abrolhos Bank, eastern Brazil. IP - initial phase and TP - terminal phase individuals.

\begin{tabular}{llc}
\hline Parrotfish species & \multicolumn{1}{c}{ Coral species } & $\begin{array}{c}\text { Number of } \\
\text { predatory events }\end{array}$ \\
\hline Scarus trispinosus & Montastrea cavernosa & 11 \\
& Favia gravida & 3 \\
& Siderastrea spp. & 2 \\
& Mussismilia hartti & 1 \\
& Porites astreoides & 1 \\
& Total & 18 \\
Sparisoma amplum (IP) & Mussismilia braziliensis & 11 \\
& Montastrea cavernosa & 3 \\
\multirow{5}{*}{ Sparisoma amplum (TP) } & Siderastrea spp. & 3 \\
& Mussismilia braziliensis & 8 \\
& Montastrea cavernosa & 4 \\
& Siderastrea spp. & 2 \\
& Total & 31 \\
\hline
\end{tabular}
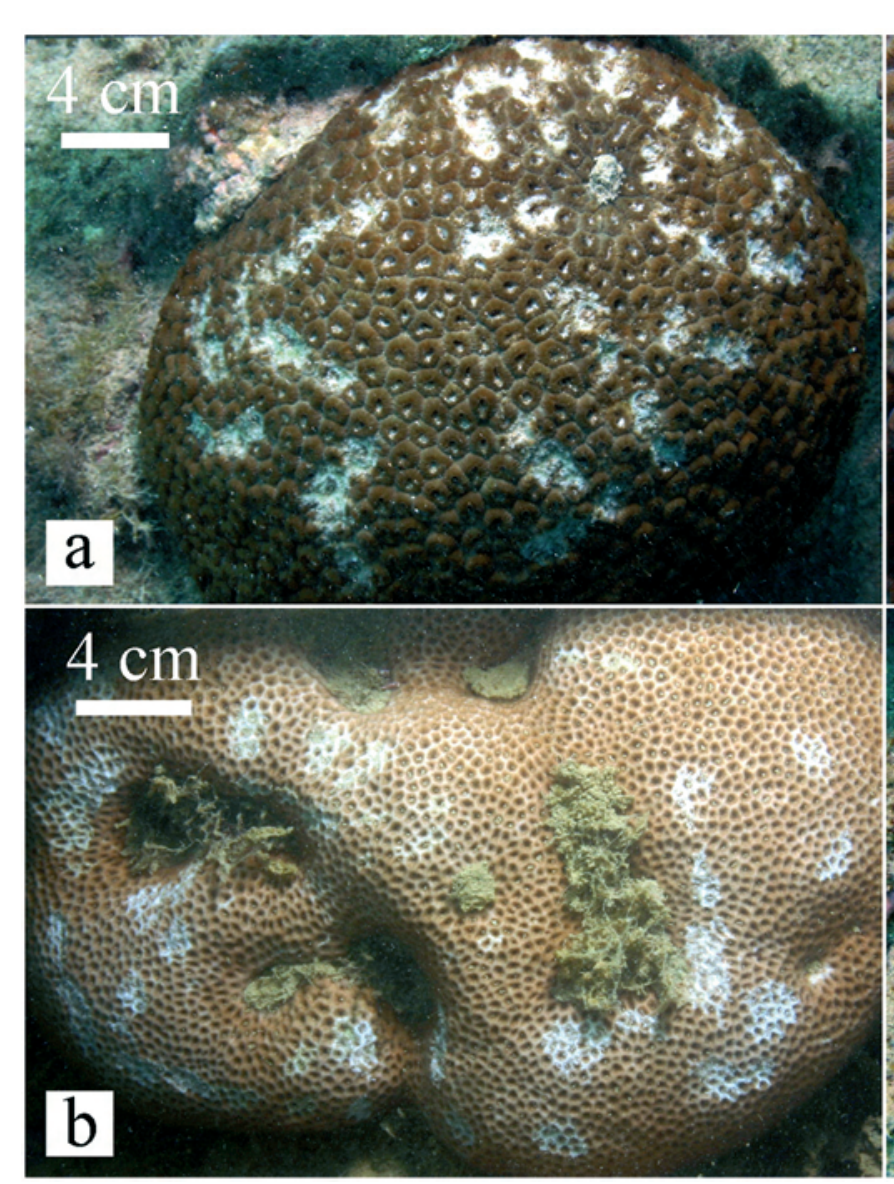

= 15), followed by F. gravida and Siderastrea spp. $(\mathrm{n}=1$ for both species).

Bite size. Mean surface area of live coral tissue removed per bite of Sp. amplum $\left(0.79 \pm 0.05(\mathrm{SE}) \mathrm{cm}^{2} ; \mathrm{n}=6\right)$ and $S c$.

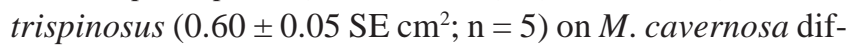
fered significantly ( $t=2.62, \mathrm{p}=0.027$; Fig. 4). Bites of $S c$. trispinosus on crustose calcareous algae also differed significantly according to body size, since individuals in the 20$40 \mathrm{~cm}$ TL size category took smaller bites $\left(0.04 \pm 0.02 \mathrm{SE} \mathrm{cm} \mathrm{cm}^{2}\right.$; $\mathrm{n}=10)$ than individuals $>40 \mathrm{~cm}$ TL $\left(0.55 \pm 0.19 \mathrm{SE} \mathrm{cm}^{2} ; \mathrm{n}=10\right)$ $(t=8.09, \mathrm{p}<0.001$; Fig. 6).

Coral abundance and grazing selectivity of Sp. amplum for different coral species. Mussismilia braziliensis was the most abundant coral species at Timbebas Reef (6.1\% of relative cover), followed by Siderastrea spp. (3.1\%), M. cavernosa (1.21\%), M. hartti (1.2\%), Mussismilia hispida (0.3\%), F. gravida (0.2\%), Agaricia agaricites (0.13\%) and P. astreoides (0.10\%). Electivity index showed that Sp. amplum and Sc. trispinosus fed selectively on $M$. braziliensis $(E i=0.11)$ and F. gravida $(E i=0.36)$ respectively, while avoiding the other coral species ( $E i<0$ for all species) (Fig. 7).
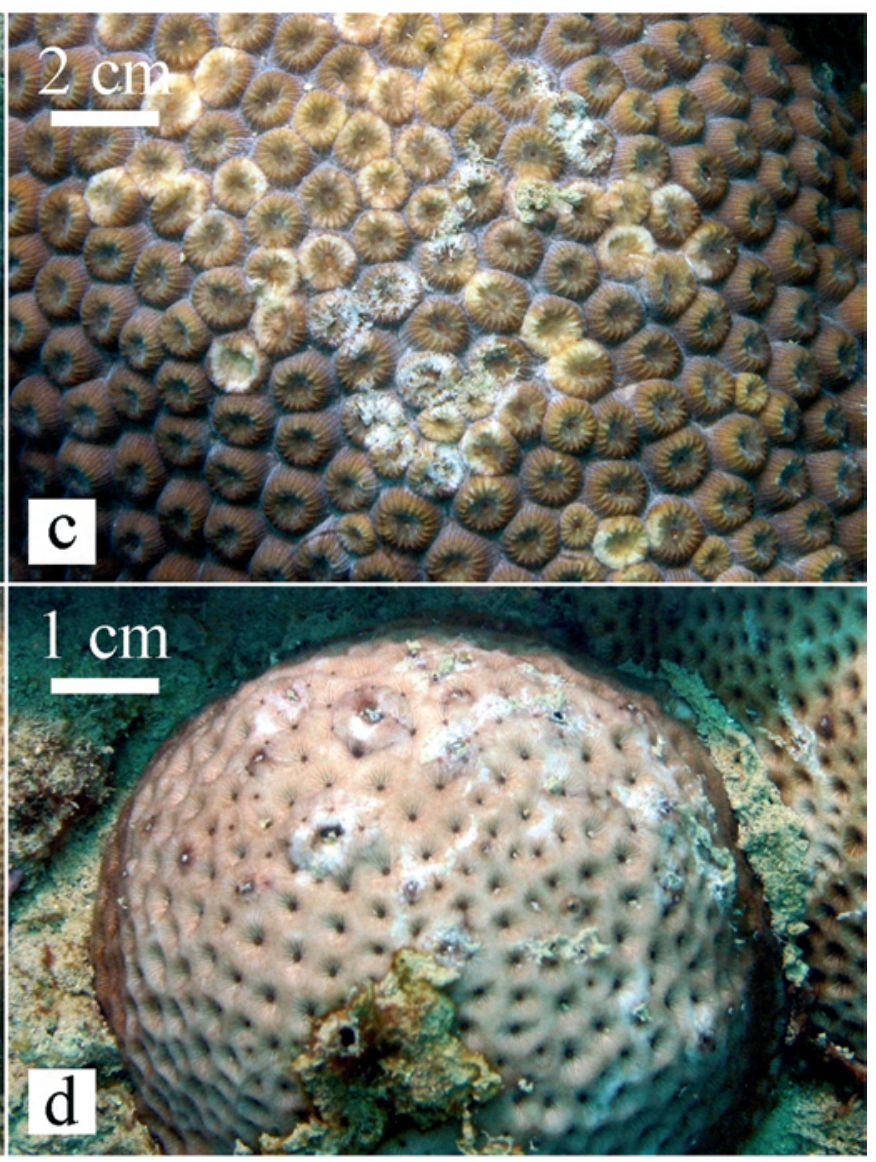

Fig. 4. Bite scars of Sparisoma amplum (a and b) and Scarus trispinosus (c and d) on the corals Montastrea cavernosa (top) and Siderastrea spp. (bottom). 


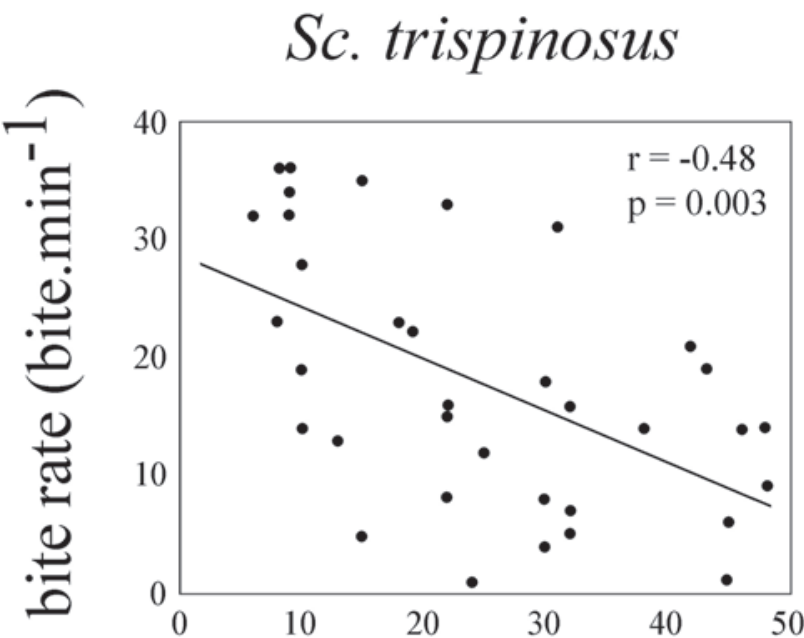

Sp. amplum

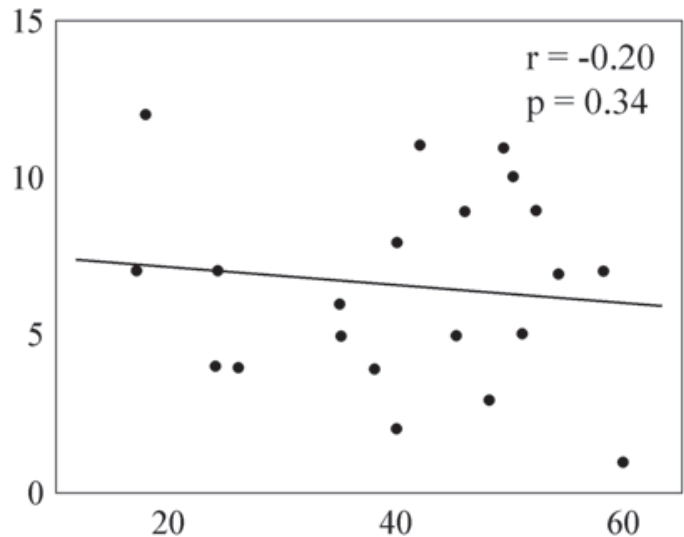

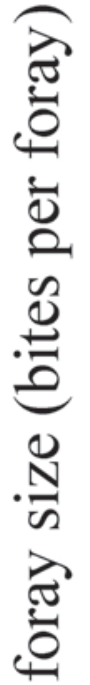
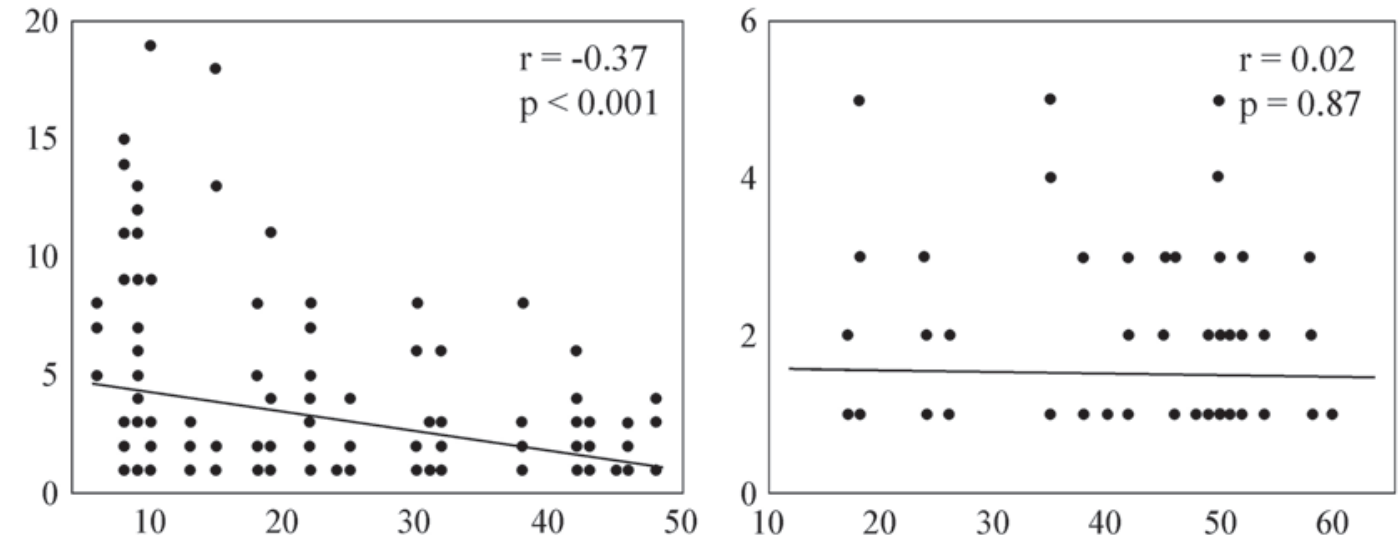

\section{body size $(\mathrm{cm})$}

Fig. 5. Relationship between body size (total length) and bite rate (top) and body size and foray size (bottom) for Scarus trispinosus and Sparisoma amplum.
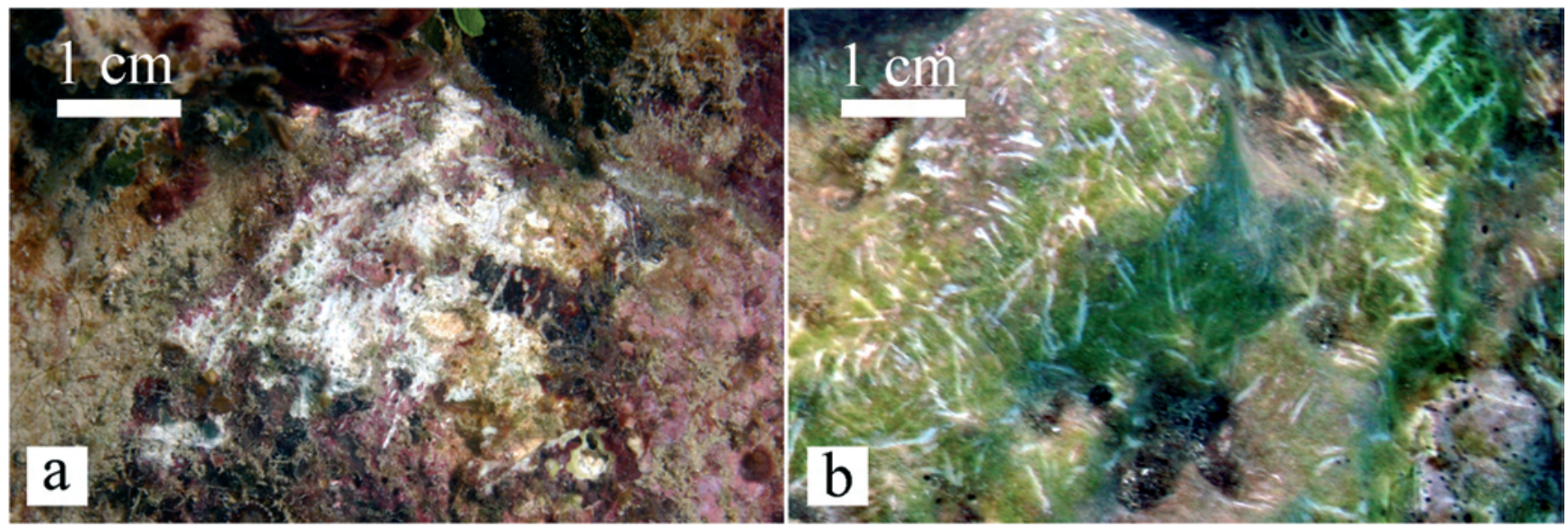

Fig. 6. (a) Scars caused by large individuals ( $>40 \mathrm{~cm}$ TL) and (b) scrapes caused by small individuals (20-40 cm TL) of Scarus trispinosus on crustose calcareous algae. 
Table 2. Feeding rate and foray size of Scarus trispinosus and Sparisoma amplum. Values given are mean \pm SE. IP initial phase and TP - terminal phase individuals.

\begin{tabular}{|c|c|c|}
\hline $\begin{array}{l}\text { Parrotfish species (life } \\
\text { phase) }\end{array}$ & $\begin{array}{l}\text { Feeding rate } \\
\text { (bite. } \mathrm{min}^{-1} \text { ) }\end{array}$ & $\begin{array}{c}\text { Foray size (bites } \\
\text { per foray) }\end{array}$ \\
\hline Scarus trispinosus & $17.8 \pm 1.8$ & $3.0 \pm 0.2$ \\
\hline $\begin{array}{l}\text { Sparisoma amplum } \\
\text { (IP) }\end{array}$ & $7.0 \pm 0.7$ & $1.7 \pm 0.1$ \\
\hline $\begin{array}{l}\text { Sparisoma amplum } \\
\text { (TP) }\end{array}$ & $6.1 \pm 0.9$ & $1.3 \pm 0.01$ \\
\hline
\end{tabular}

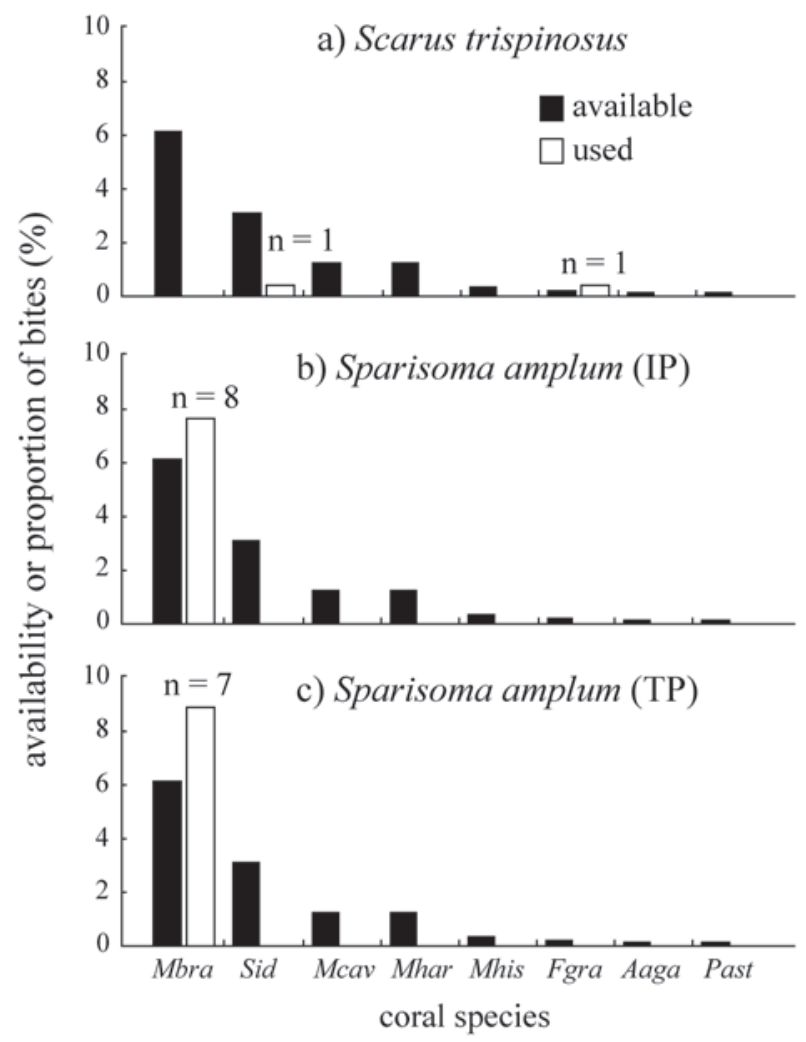

Fig. 7. Proportion of bites taken by Scarus trispinosus and Sparisoma amplum on live corals and availability (\%) of different coral species. Numbers above bars indicate the absolute number of bites taken on each coral species. Coral species: Mbra - Mussismilia braziliensis; Sid - Siderastrea spp.; Mcav - Montastrea cavernosa; Mhar - Mussismilia hartti; Mhis - Mussismilia hispida; Fgra - Favia gravida; Aaga Agaricia agaricites; Past - Porites astreoides.

\section{Discussion}

Records of live coral predation by parrotfishes in the Caribbean remote to the 1970's (Frydl, 1979) and at least four species are known to prey upon live corals (Sp. viride, Sc. vetula, Sc. guacamaia and Sp. aurofrenatum). Due to its large bite size and higher preference for live corals, Sp. viride is considered the major parrotfish coral predator in that region (Bruckner \& Bruckner, 1998; Miller \& Hay, 1998; Reyes-
Nivia et al., 2004). In Bonaire, Netherland Antilles, IP and TP Sp. viride individuals allocate $1.1-5.9 \%$ and $1.3-9.3 \%$ of their bites to live corals, respectively (Bruggemann et al., 1994a). Furthermore, in the back reef habitat of Carrie Bow Cay, Belize, about $2 \%$ of all Sp. viride bites are taken on live P. astreoides (Rotjan \& Lewis, 2006). Sparisoma aurofrenatum also frequently consume corals in the Caribbean, while Sc. guacamaia and Sc. vetula were rarely recorded feeding on live corals (Frydl, 1979; Bruggemann et al., 1994b; Bruckner \& Bruckner, 1998; Miller \& Hay, 1998; Rotjan \& Lewis, 2006). In the present study adult Sc. trispinosus and Sp. amplum allocated a significant amount of their bites to live corals ( $0.8 \%$ and $8.1 \%$ respectively), showing that these two species play an important role as coral predators in Brazil.

Bites from Sp. amplum on $M$. cavernosa were significantly larger than those from Sc. trispinosus of comparable body size on the same coral species. These results indicate that Sp. amplum may have a more profound impact on coral fitness and survival than Sc. trispinosus and that the former species is the most specialized parrotfish coral predator in eastern Brazilian reefs. It is important to note that the estimate of bite size obtained for Sp. amplum in the present study was smaller than that obtained for its Caribbean sister taxa (Sp. viride) by Reyes-Nivia et al. (2004) (between 1.83 and $3.51 \mathrm{~cm}^{2}$ ), but similar to the estimate obtained for Sp. viride by Bruggemann et al. (1994b) (about $0.60 \mathrm{~cm}^{2}$ for individuals with $45 \mathrm{~cm}$ TL). Differences between results from these studies are probably not related to actual differences in the size of bites from Sp. viride and Sp. amplum, but to differences in the methodologies used, since in the study of Reyes-Nivia et al. (2004) the greatest values of length and height measured directly in the field were used (thus possibly overestimating bite size) while in the study of Bruggemann et al. (1994b), as well as in this study, all contours and irregularities of each scar were considered.

Parrotfishes are known to feed selectively on different coral species in the Caribbean. For example, $S$. viride preys upon 18 species of scleractinian corals (Frydl, 1979; Bruckner \& Bruckner, 1998), but affects primarily only colonies of the Montastrea annularis species complex and Colpophyllia natans (Bruckner \& Bruckner, 1998, 2002; Reyes-Nivia et al., 2004). Also, Rotjan \& Lewis (2006) showed that unidentified parrotfish species, possibly Sp. aurofrenatum and Sp. viride, feed selectively on colonies of the Montastrea annularis species complex in Belize. The results obtained in the present study showed that Sc. trispinosus and Sp. amplum feed preferentially on F. gravida and M. braziliensis respectively. However, the results obtained for $S c$. trispinosus must be interpreted with cautions due to the few records of coral predation by this species $(n=2$; see Fig. 7). By searching the literature, Rotjan \& Lewis (2006) showed that there is no clear relationship between parrotfish coral predation intensity and coral skeletal density, there- 
fore concluding that the preference of parrotfishes for different coral species may be actually related to differences in the nutritional quality of the coral tissue. Besides the supposedly nutritional benefits of ingesting the coral tissue, focused biting behavior by Sp. amplum on M. braziliensis may be also related to territorial marking. This latter hypothesis is supported by the fact that predation often occurs near territory boundaries, leaving distinctive, large and noticeable white marks (see Fig. 3). Similar findings were obtained for S. viride in the Caribbean (Bruckner et al., 2000).

Bonaldo et al. (2005) present data on bite rates and feeding selectivity for Sp. amplum, Sp. axillare and S. frondosum from Fernando de Noronha Archipelago, off northeastern Brazil. They recorded no parrotfish individuals feeding on live corals, and explained their results by the rarity of hard corals at their study site. This is a plausible explanation since records of coral predation by parrotfishes were relatively rarer in areas with low coral cover in the Abrolhos Bank (e.g. Itacolomis Reef; see Fig. 2). In their study, mean bite rates of Sp. amplum ranged from about 0.5 to 6 bites. $\mathrm{min}^{-1}$ for IP individuals and from 0.5 to 2.5 bites. $\mathrm{min}^{-1}$ for TP ones, with a significant difference between the two life phases. Although the bite rate estimates obtained for Sp. amplum in the present study were relatively higher $\left(7.0 \pm 0.7\right.$ and $6.1 \pm 0.9$ bites. min $^{-}$ ${ }^{1}$ for IP and TP individuals respectively), IP individuals also tended to feed at higher rates than TP ones. Differences in magnitude between the bite rate estimates from Bonaldo et al. (2005) and this study may be related to differences in the methodology used or to habitat mediated effects on the foraging activity of parrotfishes. Bonaldo et al. (2005) used 3-5 min observation periods, and stated that the lower feeding rates obtained for TP individuals were due to the time spent by these fishes in other activities than feeding. In the present study shorter observation periods ( 1 min) were used, thus avoiding the interference of behaviors unrelated to feeding.

One of the most important implications of the different feeding modes of parrotfishes is the relative amount of bioerosion. Only excavating species and a few large scrapers remove significant quantities of coral and coralline substratum while feeding, and thus have a disproportionately large effect on the microhabitat structure of reefs and their associated community (Bellwood \& Choat, 1990; Bellwood et al., 2003). Main criteria for discriminating scraping and excavating species are behavioral and morphological. Scrapers take small bites, feed at low rates and take longer forays than excavators, also possessing a weaker but more mobile jaw apparatus. Our results indicate that Sp. amplum may be primarily recognized as an excavating species, while $S c$. trispinosus may be recognized as a scraper or excavator depending on its body size. All juvenile parrotfishes are scrapers (Bellwood \& Choat, 1990), and their excavating potential may be related to body size (Bruggemann et al., 1996). We found that larger Sc. trispinosus individuals feed at lower rates and leave larger scars than smaller individu- als, performing a more intense bioerosion activity. However, even large bodied Sc. trispinosus individuals show a smaller excavating potential than similar sized Sp. amplum. Despite its lower excavating potential, Sc. trispinosus is the most abundant parrotfish species in the Abrolhos Bank (FranciniFilho \& Moura, 2008), thus possibly causing a greater impact on coral fitness and survival. The functional classification we propose herein corresponds to the classification proposed by Bellwood \& Choat (1990) for the putative sister taxa of Sc. trispinosus (Sc. coeruleus) and the sister taxa of Sp. amplum (Sp. viride), indicating that these two congeneric species pairs play similar ecological roles in different geographic regions (Brazil and Caribbean).

Ferreira \& Gonçalves (2006) found larger amounts of carbonate material in stomach contents of Sp. amplum in comparisons to other parrotfishes in the Abrolhos Archipelago. The larger and deeper bites, the removal of large amounts of underlying skeleton when preying upon live coral, and the preference for crustose coralline algae (Ferreira \& Gonçalves, 2006) may explain why Sp. amplum have larger carbonate fractions in their guts than other species.

Given the increase on natural and anthropogenic threats to Brazilian corals (Leão \& Kikuchi, 2005; Dutra et al., 2006; Francini-Filho et al., 2008), further detailed studies are needed to a better understanding of the relative contribution of parrotfish predation to coral fitness and survival. Similarly to other studies (e.g. Rotjan \& Lewis, 2006), we showed here that coral predation by parrotfishes produces distinctive grazing scrapes or scars. Since direct observations of live coral predation by parrotfishes may be rare, the presence of such scrapes or scars may well be used to estimate the incidence of parrotfish grazing on different coral species and habitats in Brazil.

\section{Acknowledgments}

We thank Andrew W. Bruckner and Les Kaufman for their helpful comments on the research and for reviewing early versions of the manuscript. Roberta M. Bonaldo, Andy Rotjan and one anonymous referee for greatly improving the manuscript. Guilherme Dutra for advice on the research. Danilo L. Araújo for logistical support. Grazyela Fiuza-Lima, Eric J. Comin, Pedro M. Meirelles, Rodrigo M. Reis, Aneilton Diocleciano do Carmo and Igor Cruz for field assistance. Parque Nacional Marinho de Abrolhos/IBAMA (through Marcelo Skaf, Henrique H. Ilha and Marcello Lourenço), and Reserva Extrativista Marinha do Corumbau/IBAMA (through Ronaldo F. Oliveira and Alexandre Z. Cordeiro) for logistical support and research permits. Financial support was provided by the Fundação de Amparo à Pesquisa do Estado de São Paulo (FAPESP), International Society for Reefs Studies (ISRS), BP Conservation Programme, and Conservation International. This is contribution number four of the Marine Management Areas Science Program, Brazil Node. 


\section{Literature Cited}

Bellwood, D. R. \& J. H. Choat. 1990. A functional analysis of grazing in parrotfishes (family Scaridae): the ecological implications. Environmental Biology of Fishes, 28: 189-214.

Bellwood, D. R., A. S. Hoey \& J. H. Choat. 2003. Limited functional redundancy in high diversity systems: resilience and ecosystem function on coral reefs. Ecology Letters, 6: 281-285.

Bellwood, D.R., T.P. Hughes, C. Folke \& M. Nÿstrom. 2004. Confronting the coral reef crisis. Nature, 429: 827-833.

Bonaldo, R. M., J. P. Krajewski, C. Sazima \& I. Sazima. 2005. Foraging activity and resource use by three parrotfish species at Fernando de Noronha Archipelago, tropical West Atlantic. Marine Biology, 149: 423-433.

Bruckner, A. W. \& R. J. Bruckner. 1998. Destruction of coral by Sparisoma viride. Coral Reefs, 17: 350.

Bruckner, A. W. \& R. J. Bruckner. 2000. Coral predation by Sparisoma viride and lack of relationship with coral disease. Proceedings of the 9th International Coral Reef Symposium, 2: 1245-1249.

Bruckner, A. W., R. J. Bruckner \& P. Sollins. 2000. Parrotfish predation on live coral: "spot biting” and "focused biting”. Coral Reefs, 19: 50.

Bruggemann, J. H., A. M. van Kessel, J. M. van Rooji \& A. M. Breeman. 1996. Bioerosion and sediment ingestion by the Caribbean parrotfish Scarus vetula and Sparisoma viride: Implications of fish size, feeding mode and habitat use. Marine Ecology Progress Series, 134: 59-71.

Bruggemann, J. H., M. W. M. Kuyper \& A. M. Breeman. 1994b. Comparative analysis of foraging and habitat use by the sympatric Caribbean parrotfish Scarus vetula and Sparisoma viride (Scaridae). Marine Ecology Progress Series, 112: 51-66.

Bruggemann, J. H., M. J. H. van Oppen \& A. M. Breeman. 1994a. Foraging by the stoplight parrotfish, Sparisoma viride. 1. Food selection in different, socially determined habitats. Marine Ecology Progress Series, 106: 41-55.

Dutra, G. F., G. R. Allen, T. Werner \& S. A. McKenna. 2006. A rapid marine biodiversity assessment of the Abrolhos Bank, Bahia, Brazil. RAP Bulletin of Biological Assessment, 38, Conservation International, Washington DC. 160p.

Ferreira, C. E. L. \& E. A. Gonçalves. 2006. Community structure and diet of roving herbivorous reef fishes in the Abrolhos Archipelago, south-western Atlantic. Journal of Fish Biology, 69: 1533-1551.

Francini-Filho, R. B. \& R. L. Moura. 2008. Dynamics of fish assemblages on coral reefs subjected to different management regimes in the Abrolhos Bank, eastern Brazil. Aquatic Conservation: Marine and Freshwater Ecosystems. DOI: 10.1002/aqc.966

Francini-Filho, R. B., R. L. Moura, F. L. Thompson, R. D. Reis, L. Kaufman, R. K. P. Kikuchi \& Z. M. A. N. Leão. 2008. Diseases leading to accelerated decline of reef corals in the largest South Atlantic reef complex (Abrolhos Bank, eastern Brazil). Marine Pollution Bulletin, 56(5): 1008-1014.

Frydl, P. 1979. The effect of parrotfish (Scaridae) on coral in Barbados, W.I. Internationale Revue der gesamten Hydrobiologie und Hydrographie, 64(3): 737-748.

Gasparini, J. L., S. R. Floeter \& J. C. Joyeux. 2004. Sparisoma tuiupiranga, a new species of parrotfish (Perciformes: Labroidae: Scaridae) from Brazil, with comments on the evolution of the genus. Zootaxa, 384: 1-14.

Hughes, T. P. 1994. Catastrophes, phase shifts, and large-scale degradation of a Caribbean coral reef. Science, 265: 1547-1551.

Ivlev, V. S. 1961. Experimental ecology of the feeding of fishes. New Haven, Yale University Press. 302p.

Kohler, K. E. \& S. M. Gill. 2006. Coral Point Count with Excel extensions (CPCe): A Visual Basic program for the determination of coral and substrate coverage using random point count methodology. Computers and Geosciences, 32(9): 1259-1269.

Krebs, C. J. 1989. Ecological methodology. New York, Harper Collins. 654p.

Leão, Z.M.A.N. \& R.K.P. Kikuchi. 2001. The Abrolhos Reefs of Brazil. pp. 83-96. In: Seeliger U. \& B. Kjerfve (Eds.). Coastal Marine Ecosystems of Latin America. Berlin, Springer-Verlag. 360p.

Leão, Z.M.A.N. \& R.K.P. Kikuchi. 2005. A relic coral fauna threatened by global changes and human activities, Eastern Brazil. Marine Pollution Bulletin, 51(5-7): 599-611.

McClanahan, T. R., V. Hendrick, M. J. Rodrigues \& N. V. C. Polunin. 1999. Varying responses of herbivorous and invertebrate-feeding fishes to macroalgal reduction on a coral reef. Coral Reefs, 18: 195-203.

Miller, M. W. \& M. E. Hay. 1998. Effects of fish predation and seaweed competition on the survival and growth of corals. Oecologia, 113: 321-238.

Moura R. L., J. L. Figueiredo \& I. Sazima. 2001. A new parrotfish (Scaridae) from Brazil, and revalidation of Sparisoma amplum (Ranzani, 1842), Sparisoma frondosum (Agassiz, 1831), Sparisoma axillare (Steindachner, 1878) and Scarus trispinosus Valenciennes, 1840. Bulletin of Marine Science, 68(3): 505524.

Moura, R. L. \& R. B. Francini-Filho. 2006. Reef and shore fishes of the Abrolhos Region, Brazil. pp. 40-55. In: Dutra, G. F., G. R. Allen, T. Werner \& S. A. McKenna (Eds.). A Rapid Marine Biodiversity Assessment of the Abrolhos Bank, Bahia, Brazil. RAP Bulletin of Biological Assessment 38, Conservation International, Washington DC.

Reyes-Nivia M. C., J. Garzón-Ferreira \& A. Rodríguez-Ramírez. 2004. Depredación de coral vivo por peces en el Parque Nacional Natural Tayrona, Caribe colombiano. Revista de Biología Tropical, 52(4): 883-895.

Robertson, D. R., F. Karg, R. L. Moura, B. C. Victor \& G. Bernardi. 2006. Mechanisms of speciation and faunal enrichment in Atlantic parrotfishes. Molecular Phylogenetics and Evolution, 40: 795-807.

Robertson, D. R. \& R. R. Warner. 1978. Sexual patterns in the labroid fishes of the western Caribbean, II.The parrotfishes (Scaridae). Smithsonian Contributions to Zoology, 255: 1-26.

Rotjan, R. D. \& S. A. Lewis. 2005. Selective predation by parrotfishes on the reef coral Porites astreoides. Marine Ecology Progress Series, 305: 193-201.

Rotjan, R. D. \& S. A. Lewis. 2006. Parrotfish abundance and selective corallivory on a Belizean coral reef. Journal of Experimental Marine Biology and Ecology, 335: 292-301.

Sánchez, J. A., M. F. Gil, L. H. Chasqui \& E. M. Alvarado. 2004. Grazing dynamics on a Caribbean reef-building coral. Coral Reefs, 23: 578-583. 
Streelman, J. T., M. Alfaro, M. W. Westneat, D. R. Bellwood \& S. A. Karl. 2002. Evolutionary history of the parrotfishes: biogeography, ecomorphology, and comparative diversity. Evolution, 56(5): 961-971.

Van Veghel, M. W. \& R. P. M. Bak. 1994. Reproductive characteristics of the polymorphic Caribbean reef budding coral Montastrea annularis. III. Reproduction in damaged and regenerating colonies. Marine Ecology Progress Series, 109: 229233.

Zar, J. H. 1999. Biostatistical analysis. 4th ed. New Jersey, PrenticeHall. 663p.

Accepted May 2008

Published June 28, 2008 